УДК 42(07)

\title{
МОВНЕ ТЕСТУВАННЯ ТА ОЦІНЮВАННЯ: УКРАЇНСЬКИЙ ДОСВІД
}

\author{
Квасова О. Г., Писанко М. Л. \\ olga.kvasova.1610@gmail.com; marijka2177@gmail.com \\ Київський національний університет імені Тараса Шевченка, \\ Київський наиіональний лінгвістичний університет \\ Дата надходження 30.04.2018. Рекомендовано до друку 28.05.2018.
}

\begin{abstract}
Анотація. У статті представлено огляд сучасного стану мовного тестування й оцінювання в Україні. Авторки статті поділились досвідом роботи Всеукраїнської асоціації з мовного тестування й оцінювання щодо підвищення кваліфікації викладачів у галузі контролю й оцінювання досягнень студентів у вивченні іноземних мов. Описано співпрацю з міжнародними організаціями з мовного тестування й оцінювання. Наведено результати міжнародних і вітчизняних досліджень щодо визначення рівня обізнаності українських викладачів іноземних мов 3 питань контролю й оцінювання іншомовних навичок і вмінь тих, хто вивчає іноземні мови.
\end{abstract}

Ключові слова: контроль й оцінювання, мовне тестування й оцінювання, викладачі іноземних мов.

Квасова О. Г., Писанко М. Л. Киевский университет имени Тараса Шевченко, Киевский национальный лингвистический университет

Языковое тестирование и оценивание: украинский опыт

Аннотация. В статье представлен обзор современного состояния языкового тестирования и оценивания в Украине. Авторы статьи делятся опытом работы Всеукраинской ассоциации по языковому тестированию и оцениванию в рамках повышения квалификации преподавателей в сфере контроля и оценивания достижений студентов в изучении иностранных языков. Описано сотрудничество с международными организациями по языковому тестированию и оцениванию. Приведены результаты международных и отечественных исследований, нацеленных на определение уровня грамотности украинских преподавателей иностранных языков в сфере контроля и оценивания иноязычных навыков и умений изучающих иностранные языки.

Ключевые слова: контроль и оценивание, языковое тестирование и оценивание, преподаватели иностранных языков.

Kvasova O., Pysanko M. Taras Shevchenko National University of Kyiv, Kyiv National Linguistic University

Language testing and assessment: Ukrainian experience

Abstract. Language testing and assessment (LTA) has gained importance due to the introduction of ECTS in Ukrainian universities and the increased need in conducting summative tests to account for learning achievements. A team of teachers trained in LTA within the British Council Ukraine project Assessment in ELT have been networking ever since contributing to the dissemination of knowledge about testing by conducting workshops and publishing broadly. This collaboration led to the foundation of the Ukrainian Association for Language Testing and Assessment (UALTA) aimed at enhancing LTA literacy among university FL teachers across the country. Reviewing Ukrainian LTA practices. Surveying teachers' assessment literacy and needs in LTA training. The membership of UALTA is steadily growing, thereby giving credit to the high quality of workshops conducted by international and Ukrainian experts, and the dissemination events conducted by the UALTA participants at their universities. A survey conducted in May 2017 elicited teachers' perceptions of the efficacy of Association's activities. Engagement of 34 UALTA and 21 non-UALTA members enabled comparison of LTA literacy of the two groups of respondents during 2015-2017. The data provided evidence of UALTA members trying to abide by the testing cycle and being more testing-wise than their counterparts. Quite much has been done to enhance the assessment literacy of university FL teachers, the respondents confirmed. UALTA's prospects are aimed at mastering portfolios, self and peer-assessment. The Association is committed to collaborate within different research projects and activities to promote teachers' assessment literacy in Ukraine.

Key words: control and assessment, language testing and assessment, foreign language teachers. 
Постановка проблеми. Інтеграція України в європейський освітній простір вимагає реформування української системи освіти, зокрема у вивченні, навчанні й оцінюванні іноземних мов (IM). Зважаючи на міжнародні стандарти щодо рівнів володіння IM, а також визначення якості володіння IM шляхом складання міжнародних екзаменів (UCLES, IELTS, APTIS, TOEFL тощо), Україна приєдналася до інших європейських країн, які обрали тестування як інструмент вимірювання й оцінювання іншомовних навичок і вмінь випускників закладів загальної середньої освіти, а також для проведення незалежних зовнішніх іспитів.

Аналіз останніх досліджень і публікацій. Тому останнім часом увага європейської (К. Вогт, Е. Гріна, О. Інбар-Луріе, Д. Цагарі та ін.) й української (Л. В. Гнаповської, Т. І. Кавицька, О. Г. Квасової та ін.) методичної спільноти зосереджена на необхідності підвищувати професійний рівень учителів / викладачів ІМ щодо контролю й оцінювання іншомовних навичок і вмінь: здатності розробляти й укладати власні тести, критично оцінювати наявні тести й інші інструменти контролю й оцінки, розвивати вміння розробляти критерії й параметри оцінювання, а також шкали нарахування балів для оцінювання різних видів мовленнєвої діяльності. Як свідчать дослідження згаданих науковців, учителям / викладачам IM часто бракує теоретичних знань 3 мовного тестування й оцінювання, до того ж вони не знайомі $з$ наявними інструментами й методами контролю й оцінювання іншомовних навичок і вмінь учнів / студентів. Зважаючи на це, в межах європейського проекту підвищення кваліфікації вчителів англійської мови (http://taleproject.eu) створено он-лайн курс і низку навчальних матеріалів 3 мовного тестування й оцінювання (МТО) для вчителів / викладачів IM та студентів - майбутніх вчителів IM.

Метою статті $\epsilon$ огляд сучасного стану мовного тестування й оцінювання в Україні.

Основні результати дослідження. В Україні МТО набуло актуальності з часів вступу України до Болонського процесу в 2005 році. В той же час було впроваджене зовнішнє незалежне оцінювання випускників закладів загальної середньої освіти, ініційоване урядом. У відповідь на потребу в підготовці висококваліфікованих фахівців з МТО Британська Рада в Україні започаткувала проект “Оцінювання у навчанні англійської мови як іноземної” за участі Міністерства освіти і науки України. За час (2006-2007рр.), доки тривав проект, команда 3 30-ти вчителів закладів загальної середньої освіти й викладачів закладів вищої освіти (3ВО) успішно опанувала основи теорії та практики мовного тестування й оцінювання, таким чином зробивши внесок у розвиток вітчизняної педагогічної науки.

Згодом завданням проекту стала організація й проведення поточного та підсумкового контролю в ЗВО, як украй необхідного через упровадження кредитно-модульної системи навчання i, зокрема, Європейської системи залікових балів і кредитів. Учасники проекту поділились набутим досвідом з МТО зі своїми колегами під час спеціально організованих семінарів і майстер-класів у ЗВО України. Окрім допомоги, яку надавали учасники проекту в процесі укладання тестів і їх упровадження, вони продовжували обмінюватися теоретичними знаннями й практичним досвідом на наукових конференціях і в наукових публікаціях. Вийшли друком серії методичних посібників з МТО як для вчителів / викладачів, так і для учнів / студентів. Семінари щодо розвитку обізнаності в галузі МТО стали ефективним засобом підвищення рівня кваліфікації вчителів і викладачів англійської мови, завдяки координаторам і методистам, які проводили їх у різних ЗВО України. Також вийшов з друку посібник “Основи тестування іншомовних навичок і вмінь” (Квасова, 2009), призначений як для вчителів / викладачів IM, так і для студентів мовних факультетів (майбутніх учителів IM). Таким чином, учасники проекту, ініційованого Британською Радою в Україні, які й надалі продовжують співпрацю, зробили суттєвий внесок у розвиток методики МТО в Україні.

Наступним кроком стало визначення потреби проведення спеціальних тренінгів 3 контролю й оцінювання для викладачів. Із самого початку дослідження, яке проводилось К. Вогт і Д. Цагарі (2014) в семи європейських країнах, а також було проведене і в Україні, підтвердило, 
що українські вчителі й викладачі IM та їхні європейські колеги мають однаковий рівень обізнаності в галузі МТО. Тим не менш, розбіжності освітніх традицій у країнах Європейського Союзу й пострадянській Україні зумовили проведення додаткового дослідження і визначення потреб українських викладачів (Kvasova, Kavytska 2014). Результати дослідження були використані для розроблення програми курсу підвищення кваліфікації викладачів. Курс, який уміщує шість модулів, був апробований авторами дослідження: модуль I - 2009-2010 pр., модуль II - 2013 p. (Kvasova 2014).

Курс, розроблений з опертям на теоретичні засади, був адаптований з урахуванням потреб цільової аудиторії. Заняття передбачали як індивідуальну, так і групову й командну роботу, читання й обговорення, а також виконання завдань. Курс оцінювали як українські, так і міжнародні спостерігачі, які відзначили його новаторський характер, визначили труднощі його впровадження i, відповідно, необхідність у підтримці фахівців з МТО. Така підтримка була надана Міжнародною асоціацією з МТO (ILTA). Президент ILTA Ентоні Грін (2014-2015 р.p) у вересні 2015 р. провів дводенний семінар у Києві. Його головною метою було заснування Всеукраїнської асоціації з МТО (ВУАМТО), яка стала точкою відліку поширення обізнаності з МТО серед викладачів ЗВО по всій країні. Сьогодні ВУАМТО нараховує 5 регіональних центрів, які утримуються за рахунок членських внесків. Фінансування 3 боку ILTA допомогло створити веб-сайт (http://ualta.in.ua), який використовується як форум для обміну ідеями й досвідом у галузі МТО.

Протягом перших шести місяців роботи ВУАМТО кількість членів щойно створеної асоціації досягла 60-ти осіб і продовжувала зростати, оскільки в цей період до проведення семінарів і тренінгів з МТО для українських викладачів ІМ були залучені міжнародні експерти. Так, визнані фахівці з МТО - професор Ентоні Грін і доктор Крістін Кум - у вересні 2016 р. провели чотириденний семінар за участі Європейської асоціації з мовного тестування й оцінювання (EALTA); Керолін Вестбрук з Саусхемптонського університету Солент у травні 2017 р. відвідала Київ у рамках програми Erasmus + staffmobilityprogramme. Участь у зазначених семінарах дала можливість членам асоціації провести заходи й тренінги з МТО в п’яти ЗВО України.

До другої річниці створення Асоціації було вирішено визначити ефективність ії роботи, особливо зважаючи на якість підсумкового оцінювання мовленнєвих навичок і вмінь студентів. Дослідження проводилось в електронному режимі в травні 2017 р. У ньому взяли участь 55 викладачів ЗВО України, 34 з яких були членами ВУАМТО (1/3 усіх членів ВУАМТО) і 21 викладач - не були членами Асоціації. Ця вибірка дала можливість порівняти досягнення рівня обізнаності в МТО двома групами респондентів протягом 2015-2017 pp.

Перші питання дослідження мали на меті визначити, чи продовжують викладачі розробляти тести для підсумкового контролю, чи пройшли вони для цього спеціальну підготовку. Відповіді як членів ВУАМТО, так і не членів Асоціації були майже однаковими: так, вони постійно залучаються до розроблення семестрових, випускних і навіть вступних тестів або модульних контрольних робіт без проходження спеціальної підготовки, яку б мало забезпечити керівництво ЗВО або Міністерство освіти і науки. Очевидним видається й те, що відповідальність за підготовку підсумкового контролю покладено на пересічних викладачів, і ніхто не задається питанням щодо якості розроблених тестів й об'єктивності оцінювання навчальних досягнень студентів, яке залежить від кількості балів, одержаних за тест. Недостатня підтримка 3 боку керівництва ЗВО, а також невідповідність між формальними вимогами й реальністю щодо підготовки й проведення модульних контрольних робіт були зазначені респондентами як головні труднощі, що перешкоджають покращенню методів контролю й оцінювання у ЗВО.

Результати проведеного дослідження також дали можливість визначити, що респонденти члени ВУАМТО - виявились більш обізнаними щодо розроблення тестів, ніж іххні колеги не члени Асоціації. Дуже оптимістичним виявився показник щодо професійного досвіду респондентів ВУАМТО, одна третина яких мають досвід викладання IM від 6-ти до 12-ти років. Це уможливлює припущення, що в майбутньому обізнаність щодо МТО вимірюватиметься 
великою кількістю прихильників. До того ж інтерес респондентів - викладачів IM, досить молодих, проте професійно зрілих, щодо проблеми МТО й діяльності ВУАМТО свідчить про те, що проблема МТО є однією з ключових у галузі вищої освіти в Україні.

3-поміж головних засобів підвищення кваліфікації щодо МТО протягом 2015-2017 pp. члени ВУАМТО назвали семінари й майстер-класи, проведені міжнародними й вітчизняними експертами. Респонденти також висловили надію, що такі заходи значно б підвищили їхню професійну кваліфікацію й у майбутньому. Члени ВУАМТО високо оцінили запрошених міжнародних експертів, оскільки останні спонукали їх до самостійного пошуку й читання методичної літератури з МТО, незважаючи на труднощі в пошуку необхідних джерел.

Респонденти, які не $є$ членами Асоціації, також зазначили переваги участі в заходах ВУАМТО, проте вони виявилися більш обізнаними щодо можливостей, які надають вебінари й он-лайн ресурси. Виконавчий комітет Асоціації має на меті використовувати ці ефективні засоби для поширення інформації про вебінари, які проводяться за участі Міжнародної асоціації викладачів англійської мови як іноземної (IATEFL), Групи з питань MTO міжнародної асоціації викладачів англійської мови (TEASIG), Свропейської асоціації з MTO (EALTA) та ін., серед членів ВУАМТО та заохочувати іх до участі в цих заходах. Так, у нещодавній он-лайн конференції Assessment in Higher Education, що проводилась Британською Радою в рамках проекту “Ширша Європа”, взяли участь 120 представників України, набагато більше, ніж з інших країн Ширшої Європи.

Щодо інших переваг освітніх заходів, проведених під егідою ВУАМТО, акцентуємо на дотриманні членами Асоціації принципів циклічності в процесі укладання тестів: опис процедури проведення тесту й інших специфікаторів (81\% члени ВУАМТО; $42 \%$ не члени ВУАМТО), забезпечення прозорості (70\% члени ВУАМТО; 38 \% не члени ВУАМТО) й об’єктивності при нарахування балів (68\% члени ВУАМТО; $48 \%$ не члени ВУАМТО), забезпечення валідності змісту (55\% члени ВУАМТО; 51 \% не члени ВУАМТО) й зовнішньої валідності (52\% члени ВУАМТО; $38 \%$ не члени ВУАМТО) розроблених тестів, аналіз результатів та якості тестів (52\% члени ВУАМТО; $22 \%$ не члени ВУАМТО) і навіть пілотування тестів до їх затвердження й упровадження (29\% члени ВУАМТО; 0 \% не члени ВУАМТО). Більше того, відповіді респондентів - членів Асоціації - свідчать про роботу в командах при розробленні тестів, а також співпрацю й обмін досвідом з іншими колегами, тоді як респонденти, що не $€$ членами Асоціації, ще й досі здебільшого надають перевагу самостійному укладанню й розробленню тестів.

Різниця у відповідях членів і не членів ВУАМТО також виявилась і в їхніх потребах щодо організації спеціального навчання МТО на рівні підготовки майбутніх учителів IM на мовних факультетах ЗВО. Респонденти ВУАМТО висловились на підтримку необхідності введення обов'язкових модулів з МТО у межах курсу методики навчання IM, або навіть упровадження спецкурсу з МТО (50\% члени ВУАМТО; 24 \% не члени ВУАМТО), тоді як не члени Асоціації визнали достатнім запропонувати майбутнім учителям IM дотичний курс за вибором (36\% члени ВУАМТО; 42 \% не члени ВУАМТО). Респонденти ВУАМТО також дали в 3-4 рази більше позитивних відповідей щодо заохочення студентів - майбутніх учителів IM - до написання бакалаврських і магістерських дипломних робіт з методики навчання IM, присвячених проблемам МТО.

Говорячи про перспективи розвитку у викладачів-практиків умінь МТО, всі респонденти висловились про необхідність підвищення кваліфікації вчителів / викладачів IM з МТО, вказавши на он-лайн курси, розроблені в рамках проекту Erasmus + TALE, які також пілотувались членами ВУАМТО. Тим не менш, члени Асоціації наголосили на перевагах співпраці з міжнародними асоціаціями з МТО, створенні центрів професійного розвитку в регіонах України, а також необхідності підтримки з боку керівництва ЗВО й урядових структур у галузі мовної освіти в Україні. 
Як свідчить проведений огляд українського досвіду, пересічні вчителі / викладачі ІМ не шкодують ні часу, ні зусиль, щоб забезпечити об'єктивне оцінювання навчальних досягнень учнів / студентів. 2017 рік також ознаменувався посиленням позиції ВУАМТО, зробивши iї відомішою на території України. Майстер-клас Teaching Academic Writing and Assessing Academic Writing Skills, вперше проведений у вересні 2016 р. М. Л. Писанко, віце-президентом BУАМТО, користувався високим попитом через упровадження в Україні курсів з основ академічного письма в межах підготовки магістрів у ЗВО. Це дало можливість провести зазначений майстер-клас у чотирьох ЗВО України: Вінницькому державному педагогічному університеті імені Михайла Коцюбинського, Черкаському національному університеті імені Богдана Хмельницького, Національному педагогічному університеті імені М.П. Драгоманова, Сумському державному університеті.

На майстер-класах було представлено розроблену програму курсу з основ наукового письма для студентів магістратури, виділено різні жанри наукових текстів, писати які мають навчитися магістранти, представлено загальні й специфічні критерії для їх оцінювання. Також був наведений зразок модульної контрольної роботи, яку пишуть студенти по завершенні вивчення курсу, подано параметри й критерії оцінювання, а також шкали нарахування балів. Під час майстеркласу викладачі різних ЗВО мали змогу перевірити роботи студентів, визначивши ефективність розроблених критеріїв і шкал нарахування балів для оцінювання наукових текстів різних жанрів і формату модульної контрольної роботи, заповнюючи спеціально створений опитувальник, а також висловити побажання щодо їх удосконалення. Роботи перевірялись у парах для того, щоб викладачі мали змогу обговорювати нараховану кількість балів за різними критеріями. По завершенні майстер-класу мали місце дискусії, які дали можливість викладачам обмінятися досвідом і висловити свою точку зору щодо ефективності критеріїв оцінювання наукових текстів різних жанрів. На майстер-класі також ішлося про залучення інтерактивних і рефлексивних способів діяльності в процесі організації само- та взаємоконтролю й оцінювання письмових робіт студентами. Викладачам були запропоновані Опитувальник для самоперевірки й Карта коментування, які можуть бути використані студентами під час само- та взаємоперевірки письмових робіт, у такий спосіб були створені умови для аналізу й обговорення письмових робіт студентами, а також у подальшому для запобігання ними помилок у власних наукових текстах різних жанрів.

Л. В. Гнаповська, експерт ВУАМТО, організувала проведення дводенної школи професійного розвитку з питань MTO (Schools for Professional Development on LTA) для вчителів і викладачів IM. Восени 2017 р. ВУАМТО виступила співорганізатором двох конференцій, які проходили в університетах Сум і Києва, під час яких були представлені чотири майстер-класи з МТО в рамках кожної з них.

Висновки і перспективи подальших розвідок. Підсумовуючи огляд українського досвіду в галузі МТО, зазначимо, що багато було зроблено для поширення та підвищення рівня обізнаності викладачів ІМ з МТО. Подальша діяльність ВУАМТО буде спрямована на максимальну якість контролю й оцінювання у навчанні IM, а також ефективне застосування портфоліо, само- й взаємоконтролю. Асоціація відкрита до співпраці в межах різних досліджень, які мають на меті заохочення підвищення кваліфікації викладачів IM у галузі МТО в Україні, та ділиться власним досвідом на міжнародному рівні.

\section{ЛІТЕРАТУРА}

Квасова, О. Г. (2009). Основи тестування іншомовних навичок $і$ вмінь. Київ, Україна: Ленвіт. Kvasova, O. (2016). A Case of Training University teachers in Developing and Validating Classroom

Reading Test Tasks. In Tsagari D. (Ed.), Classroom-based Assessment in L2 Contexts (pp. 54-74).

Cambridge: Cambridge Scholars Publishing. 
Kvasova, O. \& Kavytska, T. (2014) The assessment competence of university foreign language teachers: A Ukrainian perspective. Language Learning in Higher Education, 4(1), 159-177.

Vogt, K. \& Tsagari, D. (2014) Assessment Literacy of Foreign Language Teachers: Findings of a European Study. Language Assessment Quarterly, 11(4), 374-402.

\section{REFERENCES}

Kvasova, O. H. (2009). Osnovy testuvannia inshomovnykh navychok i vmin'. Kyiv, Ukraina: Lenvit. Kvasova, O. (2016). A Case of Training University teachers in Developing and Validating Classroom Reading Test Tasks. In Tsagari D. (Ed.), Classroom-based Assessment in L2 Contexts (pp. 54-74). Cambridge: Cambridge Scholars Publishing.

Kvasova, O. \& Kavytska, T. (2014) The assessment competence of university foreign language teachers: A Ukrainian perspective. Language Learning in Higher Education, 4(1), 159-177.

Vogt, K. \& Tsagari, D. (2014) Assessment Literacy of Foreign Language Teachers: Findings of a European Study. Language Assessment Quarterly, 11(4), 374-402. 